\title{
"SUCCESS FEE" AS AN IMPORTANT COMPONENT OF ENSURING THE CONSTITUTIONAL RIGHT OF A PERSON TO PROFESSIONAL LEGAL ASSISTANCE
}

\author{
Viktor Zaborovskyy, \\ Professor of the Department of Civil Law and Procedure, \\ Uzhhorod national University \\ Doctor of Juridical Science, Full professor, \\ orcid.org/0000-0002-5845-7535 \\ Scopus ID: \\ https://www.scopus.com/authid/detail.uri?authorId=57211590714 \\ ResearcherID: Q-8219-2016 \\ (https://publons.com/researcher/1590333/zaborovskyy-viktor/) \\ zaborovskyviktor@gmail.com
}

\section{Summary}

The purpose of this article is to study the legal essence of such a method of calculating the lawyer's fee as «success fee», disclosing its positive and negative features, as well as the experience of the European Court of Human Rights and the experience of foreign countries in its application.

In the context of disclosing the subject of research, both to achieve the goal of scientific work and to ensure the completeness, objectivity, reliability and persuasiveness of the results, the author used a set of general and special methods that are characteristic of legal science. In particular, the origin and long historical path of development of this legal institution were studied with the help of the historical method. The system-structural method made it possible to formulate the general structure of the study, and the dialectical one - to analyze first of all legislative provisions and jurisprudence on the possibility of using the «success fee» as a way to calculate the lawyer's fee. Using a comparative legal method, the legislation of foreign countries was analyzed, which provided an opportunity to use their positive experience in terms of calculating the amount of attorney's fees.

This article discloses the scientific approaches of researchers to determine the nature of the expenses on legal assistance primarily concerning the nature of the «success fee», its positive and negative features, as well as analyzes the provisions of domestic and foreign legislators on the possibility of consolidating in the contract for legal assistance a condition that indicates such a way of calculating the amount of wages of a lawyer as a "fee for success». Significant part of the work is devoted to the analysis of the law enforcement practice of Ukrainian courts and the European Court of Human Rights, both in general as to the possibility and expediency of the existence of certain criteria for limiting its size.

It is noted that a significant number of foreign countries do not prohibit the possibility of using the «success fee», taking into account the existence of certain restrictions concerning the categories of cases, or the perception of it as an additional reward.

This article discloses the scientific approaches of researchers to determine the nature of the expenses on legal assistance primarily concerning the nature of the "success fee», its positive and negative features, as well as analyzes the provisions of domestic and foreign legislators on the possibility of consolidating in the contract for legal assistance a condition that indicates such a way of calculating the amount of wages of a lawyer as a «fee for success». Significant part of the work is devoted to the analysis of the law enforcement practice of Ukrainian courts and the European Court of Human Rights, both in general as 
to the possibility and expediency of the existence of certain criteria for limiting its size. It is noted that a significant number of foreign countries do not prohibit the possibility of using the «success fee», taking into account the existence of certain restrictions concerning the categories of cases, or the perception of it as an additional reward.

Key words: advocacy; attorney's fees; expenses on professional legal assistance; ways to calculate the amount of expenses.

\section{Introduction}

In accordance with Part 1 of Art. 26 of the Law of Ukraine "On the Bar and Advocacy» advocacy is carried out on the basis of an agreement on legal assistance. In this agreement, the lawyer and the client independently determine the procedure for calculating and paying the fee (hourly payment; sturdy (fixed) amount of money; «success fee»; customer service; combined system, etc.).

Therefore, one of the ways to calculate the amount of a lawyer's fee is the so-called "success fee». "Success fee» implies an agreement between a lawyer and a client, when the amount of remuneration depends on the result that the client is trying to achieve by resorting to professional help (Knyazev, 2005, p. 103). In the legal literature, it is also called «conditional fee» (Sarksyan, 2015, p. 99), «victory fee» (Melnychenko, 2006, p. 23). The following principle of "no win no fee» applies to this method of calculating the amount of the fee (Vityuk, 2018).

Analysis of scientific publications. Theoretical applied problems related to the calculation of the amount of attorney's fees have been the subject of research of a number of scientists, namely: D. Azarov, R.F. Asanov, R. Vityuk, O.A. Vishnevskaya, N.S. Yermakova, D.D. Luspenik, A.N. Knyazev, A.A. Maslov, R.G. Melnychenko, C.M. Sarksyan, T.O. Papii and others.

The purpose of this article is to explore the legal nature of the "success fee» as one of the ways to calculate the amount of a lawyer's fee. The main tasks that the author sets are to disclose the theoretical approaches concerning the determining of the essence of the "success fee», its positive and negative features; to explore the provisions of Ukrainian and foreign legislators, as well as the law enforcement practice of judges (including the European Court of Human Rights) concerning the possibility of using such a method of calculating the amount of attorney's fees.

\section{Origin and historical development of "success fee»}

As for the success fee, it should be perceived as a legal institution that has existed for a long time. In general, exploring the essence of the institution of remuneration for legal assistance of a lawyer (fee), it is necessary to proceed from the fact that it originated in ancient Greece and Rome, and went from perceiving it as an honorary gift for a noble deed («charity work») and regulation at the level of customary law to the appropriate normative consolidation and perception of the fee as an proper fee for advocacy with the establishment of appropriate restrictions (in particular, on the maximum size) and the criteria for determining its size (Zaborovskyy, Manzyuk \& Stoyka. 2020).

In fact, the first act concerning the remuneration of a lawyer was the law of Cintius (in honor of the people's tribune who initiated it), which is also known as "On gifts and presents». The need for the adoption of this law, according to Cornelius Tacitus, was caused by the intemperance of speakers in accepting gifts (Cornelius Tacitus. Annals. Book XV.20). One of the main restrictions was the ban on receiving remuneration until the end of the defense. Thus, in the Digests of Justinian (Book 17.1.1,6) it was noted, in addition to this restriction, that after providing protection, the lawyer had the opportunity to enter into appropriate agreements and demand remuneration (fees) through the court (Monuments of Roman law, 1997, p. 420). Although initially lawyers were not prohibited from charging an additional fee in the form of a bonus (provided that the entire amount did not exceed the established fee), but later during the reign of Emperor Marcus Aurelius Severus Alexander the possibility of interest on the successful case was banned (societatem future emolumenti) (Vishnevskaya, 2010, p. 43). The need for such a ban was that in the system of relations between 
clients and lawyers, which developed in the Roman Republic, the conditional remuneration, which is the fee for success, did not fit into the system of moral norms governing respect as well as to the relationship between the client and patron, from which the development of the Roman Advocacy took place (Maslov, 2013, p. 49).

Later, this way of calculating the amount of remuneration as a «success fee» was banned in the legislation of many European countries. Thus, in his work «Rules of the legal profession in France» (1842) M. Mollo noted that strict ban was implemented on any kind of contract under which the lawyer claims as a fee the part of the object which is the subject of dispute or its equivalent (this is a treaty Quota litis - a shameful treaty, punishable by law everywhere and always) (Mollo, 1894, p. 65).

Somewhat different situation was in Russian Empire. D. Azarov points out the fact that some boards of jurors proceeded from the fact that the lawyer's fee is often determined not only by the time spent and the work done, but also by the degree of success, that is the result of the case; such fragmentation of the fee seems to be natural because for the client the time spent and the work done are not as important as the result of the petition or defense and thus, they saw nothing bad in the consolidation of an additional fee in case of acquittal or reduction of punishment (Azarov, 2009, p. 212).

\section{Theoretical and applied problems of using the "success fee" as a way to calculate the amount of attorney's fees}

The problem of the possibility of using the "success fee» as a way to calculate the amount of a lawyer's fee has existed for a long time, and unfortunately, is still debatable in Ukraine today. Thus, the possibility of «success fee» collection from the client of a lawyer was the subject of the Civil Court of Cassation in the Supreme Court (case № 462/9002/14-ts), which motivated its decision by the fact that by implementing the principle of freedom of contract, the parties are not entitled to change the imperative requirement of the law on the subject of the contract for the provision of legal services by determining in direct or veiled form the outcome of the case by the court as part of the subject of the contract for the provision of legal services. In its decision, the Court of Cassation noted that the additional remuneration of a lawyer determined by the contract for achieving a positive decision in the case in its content and legal nature is not the price of the contract (payment for services rendered) within the meaning of Art. 632, 903 of the Civil Code of Ukraine and Art. 30 of the Law of Ukraine "On the Bar and Advocacy", but is a payment for the result itself (positive decision), the achievement of which in accordance with the terms of the contract is not dependent on the services actually provided, and therefore contradicts the basic principles of justice in Ukraine and acts of civil legislation.

A completely different view is reproduced in the decree of the Grand Chamber of the Supreme Court (case № 904/4507/18), which is motivated by the fact that the arrangements for the payment of legal assistance fees are those between a lawyer and a client, and the question of the binding nature of such an obligation may be considered within the legal relationship between the lawyer and the client. The Grand Chamber assumes that in determining the amount of compensation the court must adhere to the criterion of the reality of the costs of legal assistance, as well as the reasonableness of their amount, taking into account both whether they were actually incurred and assess their necessity.

Regarding Ukrainian legislation, the above-mentioned Art. 30 of the Law contains only the provision according to which the procedure for calculating the fee (fixed amount, hourly rate), the procedure for its payment, etc. are determined in the contract for legal assistance. In turn, Art. 30 of the Lawyer's Code of Ethics stipulates that a lawyer's right to receive unpaid fee does not depend on the result of the order, unless otherwise provided by the legal aid agreement and indicates the possibility of the lawyer applying the «success fee». The position of the Council of Advocates of Ukraine on this issue is manifested in the fact that on one hand, the lawyer has the right to receive a fee for legal assistance, the amount of which is not limited by current legislation and is determined by the agreement on legal assistance between lawyer and client and on the other hand, a lawyer is not recommended to file a claim in court for reimbursement of the success fee paid to him for the 
provided legal assistance (Decision of the Bar Council of Ukraine of April 12, 2019).

To determine our attitude to this method of calculating the lawyer's fee, we consider it necessary to disclose its positive and negative features, the legal nature of the "success fee», as well as the experience of foreign countries in its application.

The main social value of the "success fee», as noted by R.G. Melnychenko, is that it makes qualified legal aid more affordable, as there are often cases where a person is forced to waive the protection of his right only on the basis of lack of funds to pay for a lawyer. At the same time, the social significance of the fee for success, according to him, disappears when a person needs a lawyer in a criminal case, because if a person does not have the funds to pay for a lawyer, the latter will be paid by the state (Melnychenko, 2006, p. 24). V. Gvozdiy notes that in many cases, when a lawyer takes a case, he understands that it can take a lot of hours, and in complex cases it is about the work of an entire law firm. At the same time, not all customers are ready to pay such a fee at the start, which would cover the time actually lost. And here the success fee is exactly the tool that allows you to take a risk, for example, a law firm, having spent a certain amount of time, to get a reward as a result of winning, and in such cases, the success fee is just a tool to protect the rights of the client (Gvozdiy, 2018).

A similar position is held by R.F. Asanov and S.F. Akhmetov, who point out that in many cases, when the plaintiffs do not have significant savings, but at the same time are victims in a contractual, tortious or property relationship, they are faced with a dilemma: either to be without qualified protection, or to enter into a contract, under which part of the awarded amount will be available to the lawyer as his fee. In addition, the undoubted advantage of the "success fee», according to them, is its focus on a specific result, because such an approach stimulates the lawyer and improves the quality of services he provides, directs his efforts to achieve a specific goal, obtaining the appropriate result, which makes it possible to build a competent strategy for going to court and increase the likelihood of resolving the issue in favor of the client (Asanov \& Akhmetov 2007, p. 49). Any participant in the litigation, according to R.A. Chepkasova, is interested in its positive result, and hence in the effective work of its representative, and therefore many clients are ready to create material incentives for their lawyer in the hope of great interest and efficiency (Chepkasova, 2015, p. 50). Of course, this fact, as rightly noted by N.S. Yermakova, in itself should not be an argument, because a conscientious lawyer or law firm should always try to protect the interests of the wards, but to deny the objective intensification of efforts and the desire to win the case would be inappropriate (Yermakova, 2017, p. 126).

Along with the mentioned above advantages of this method of calculating the lawyer's fee D. Azarov points out that the «success fee» will contribute to the fact that lawyers will not take instructions to conduct cases which would clearly result in failure (Azarov, 2009, p. 212), thus protecting the interests of a potential client's lawyer from incurring unnecessary costs (for example, for hourly pay), in cases where the legislation and judicial practice on the legal situation of the client "clearly" not in his favor.

A number of scholars, studying the legal nature of the "success fee», point to the possibility of its use, but still proceed from the appropriate existence of certain limitations in its application. Thus, in addition to the mentioned above restriction, R.G. Melnychenko (concerning criminal cases), K.I. Gorodnikov and D.V. Vorobyov proceed from the need to perceive the «success fee" as a subsidiary condition (the contract for legal aid cannot contain only the condition of "success fee» as a condition for payment for services, because then there is a possibility that the lawyer will not be paid at all, which is inadmissible) (Gorodnikov \& Vorobyova, 2018).

At the same time, some scholars point to certain negative aspects in the use of the «success fee» as a way to calculate the amount of a lawyer's fee. In particular, O.O. Kiyashko opposes the possibility of collecting a «success fee» from the losing party because the imposition of these costs on the other party, according to her, is unfair, because such a party does not risk their money in any way (in case of losing the case the party should not pay these funds to the defense counsel, and therefore does not actually bear the court expenses on the case, and in the case of a positive court decision, the party will 
not only win the dispute, but also «earn" these funds from the losing party) (Kiyashko, 2019, p. 168). In turn, O. Vereshchagin notes that the disadvantage of such a system is the "unhealthy excitement» that it brings to court due to the tendency to increase the amount of claims in the hope of obtaining a larger amount, as well as the fact that the costs of the winning party may lay a heavy burden on the losing side (Vereshchagin, 2007, p. 175).

According to O.M. Knyazev, the disadvantage of the "success fee» is that under such conditions, the lawyer becomes a participant in a risky operation, which only partially depends on the professionalism of the lawyer, and to a greater extent depends on other circumstances, and in fact, gets involved in business, which is incompatible with his special human rights status (Knyazev, 2005, p. 106). The view of D. Azarov is also worth mentioning - he points out that this method of determining the fees may cause the situation that can exclude public trust in advocacy, namely, increasing the number of lawsuits of lawyers to their clients concerning the collection of «fee for success" (in case of including in the agreement with the lawyer the condition of "success fee» the client more easily agrees to its size, compared to what he would have to pay immediately, and when it's time to pay the fee after the case the client is tempted to evade his part of the obligation), which can lead to a negative public opinion not only in relation to a particular lawyer, but also in relation to the entire legal community (Azarov, 2009, p. 212).

\section{Experience of foreign countries and the case law of the European Court of Human Rights on the application of the «success fee»}

All this indicates the inconsistency of the positions of scholars on the feasibility of using the «success fee» as a way to calculate the amount of attorney's fees. The practice of foreign countries is just as inconsistent. First of all, it should be noted that some scholars point out the inexpediency of using the «lawyer's fee» in view of the provisions of the General Code of Rights for Lawyers of the European Communities of October 28, 1988. Yes, indeed, paragraph 3.3.1 of the Code states that a lawyer should not enter into a pactum de quota litis (an agreement under which the client undertakes to pay the lawyer a fee in the form of a sum of money or in any another form). However, there is an exception to this rule, according to which the agreement to pay a fee to a lawyer according to the value of the disputed property is not a pactum de quota litis, if the amount of the fee is determined according to the official fee scale or under the control of the competent authority the jurisdiction of which extends onto the lawyer (paragraph 3.3.3 of the Code).

As for the legislation of foreign countries, as D. Luspenik rightly points out, in some European countries such agreements have legal force (United Kingdom, Czech Republic, Slovakia, Poland, Hungary, Finland, Turkey and Greece), in others they are considered inadmissible (Germany and Ireland) (Luspenik, 2019). At the same time, in some countries there are restrictions on the use of the «success fee». In particular, in Germany there is a special law "On the remuneration of lawyers» («Rechtsanwaltsvergütungsgesetz»), Annex 1, which contains a large list of such remuneration depending on the type of advocacy. German law prohibits the «lawyer's fee» in its classical sense, but as noted by O.V. Nakushnova, in achieving an agreed result, the lawyer has the right to count on the statutory remuneration, and as a bonus may also claim an additional stipulated fee for success, while in the absence of a stipulated result it is impossible that the lawyer will not get a minimal amount of remuneration (Nakushnova, 2014, p. 82). A similar situation is typical of French law, according to which when determining the amount of attorney's fees one may take into account the result, if the contract with the client provided a condition of additional remuneration (extra amount) for a favorable outcome in the case (Petrachkov, 2010, p. 72). The Swiss legislature assumes that a lawyer cannot directly enter into a pactum quota litis agreement and refuse any payment in case of an unsatisfactory outcome of the case, but he is given the opportunity to stipulate an increase in his fee in case of winning the case - pactum de palmario (Art. 19 Swedish Code of Ethics).

The use of the "success fee» is common in the countries of the Anglo-Saxon legal system, which are primarily based on the freedom of contract, including the condition of the contract 
for legal aid as a way to calculate the amount of attorney's fees. In the United States, the success fee is allowed by state law, each with its own code of professional liability. This code is based on standard rules developed by the American Lawyers Association. T.O. Papii notes that the US success fee is part of a contingent fee that clearly sets out the criteria for determining whether a result is successful for a client either winning a case or awarding a certain amount of damages), and if a party to the lawsuit has failed or received compensation, the amount of which is less than that stipulated in the contract, the lawyer's fee is not paid or is limited (depending on the terms of the contract) (Papii, 2019, p. 417). However, the use of this method of calculating the amount of attorney's fees in the United States has certain limitations. Thus, paragraph 1.5 (d) of the 1983 Standard Rules of Professional Conduct prohibits the application of a «success fee» concerning divorce, alimony, and criminal matters. Similar restrictions exist in English law, according to which conditional fee agreements may not apply to family relationships, as well as criminal cases, with certain exceptions (Article 27 of the Access to Justice Act 1999).

In addition to researching foreign law, it is important to clarify the ECHR's attitude to the possibility of applying a "success fee» in the relationship between a lawyer and his client. Exploring the case law of this Court, D. Luspenik draws attention to the fact that the ECHR in its practice distinguishes agreements on the payment of a share of the winnings (when the obligation to pay depends on the winnings of the case and the fee is determined as a percentage of the winnings) from other types of agreements on the "success fee» (when the obligation to pay the fee also depends on the winnings of the case, but its amount is determined in a fixed amount of money, or it is a bonus added to the main amount of the fee) (Luspenik, 2019). However, the ECHR does not aim at defining in general the possibility of consolidation of such a method of calculating a lawyer's fee as a «success fee» (regardless of its type), but passes it on to the national legislator at its own discretion. Thus, in particular in the cases «Iatridis v. Greece» (2010) and "Kamasinski v. Austria» (1989), the ECHR recognizes the «success fee» agreement as valid, taking into account, first of all, the relevant na- tional legislation on their validity, whereas, for example, in «Dudgeon v. Ireland» (1983), the opposite is true.

A study of provisions of the legislation of foreign countries and ECHR practice allows us to conclude that a significant number of such countries do not prohibit the use of «success fee» (given certain restrictions on categories of cases, or its perception as an additional fee) as a way to calculate attorney's fees. The ECHR does not deny such a possibility as well.

\section{Conclusions}

One of the ways to calculate a lawyer's fee, along with an hourly fee, a fixed amount of money and others is the "success fee», which should be understood as an agreement between a lawyer and his client, which provides for the payment of fees (its amount) depending on achievement of a predetermined result, which is expected by the client and towards which the professional activity of the lawyer is directed.

A lawyer can only predict a certain outcome when providing legal assistance, but in no case is it possible to guarantee its occurrence, and therefore the lawyer's fee is based on his professional activity, not its result. Therefore, the subject of a contract for the provision of legal aid can only be the provision of certain types of legal aid, and not the result that his client expects (in particular, a certain positive decision in the case). At the same time, taking into account the principle of freedom of contract, the lawyer and the client have the opportunity to specify in the contract the condition of «success fee» as a way to calculate the lawyer's fee, according to which the achievement of a certain result should be perceived not as the subject of the contract, but as a legal fact (suspensive circumstance), with the occurrence of which the parties stipulate the need to pay the appropriate fee to the lawyer according to the level of quality of his activity.

One of the ways to calculate a lawyer's fee, along with an hourly fee, a fixed amount of money and others is the "success fee», which should be understood as an agreement between a lawyer and his client, which provides for the payment of fees (its amount) depending on achievement of a predetermined result, which is expected by the client and towards which the professional activity of the lawyer is directed. 
The positive features of the "success fee» are the increased affordability of legal aid for the population and its focus on results, which in many cases can improve the quality of such assistance, as well as protect the interests of a potential client's lawyer from incurring unnecessary costs. A necessary condition for consolidation of the "success fee" in the contract for the provision of legal aid, regardless of its type (payment of a share of the winnings in a fixed amount, or as an additional fee added to the main amount of the fee) is to establish clear criteria for determining the result, which is the aim of the professional activity of a lawyer. Given the experience of foreign countries, we consider it necessary to have certain restrictions (or even prohibitions) on the possibility of applying a «success fee» for certain categories of cases, including criminal cases and family relationships (e.g., divorce, alimony, etc.).

\section{Bibliography:}

1. Азаров, Д. (2009). К вопросу о гонораре успеха. Бизнес в законе, 4, С. 211-212.

2. Асанов, Р. Ф. \& Ахметов, С. Ф. (2007). «Гонорар успеха»: законность и целесообразность. Юридическая наука и правоохранительная практика, 1, С. 44-50.

3. Верещагин,А. (2007). «Гонорар успеха» перед лицом конституционного правосудия. Сравнительное конституционное обозрение. 1, С. 173-178.

4. Вишневская, О. А. (2010). Институт оплаты услуг адвоката в Древнем мире. Адвокатская практика, 1, С. 41- 44.

5. Вітюк, Р. (2018). Бонус для адвоката: стимул чи корупційна складова? Закон і бізнес, 31 (1381). URL: https://zib.com.ua/ua/133986-bonus_dlya_advokata_ stimul_chi_korupciyna_skladova.html

6. Гвоздій, В. (2018). Чи має право на існування гонорар успіху? Коментар для «Закон і Бізнес», 31 (1381). URL: https://zib.com.ua/ua/print/133986-bonus_dlya_ advokata_stimul_chi_korupciyna_skladova.html

7. Городников, К. И. \& Воробьева, Д. С. (2018). «Гонорар успеха» в российской правовой системе. Синергия наук. URL: http://synergy-journal.ru/archive/ article3827

8. Ермакова, Н. С. (2017). Гонорар успеха: взгляды за рубежом и в России. Законность в современном обществе: сборник статей Международной научно-практической конференции (с. 122-126). Уфа: АЭТЕРНА.

9. Заборовський, В. В., Манзюк, В. В. \& Стойка, А. В. (2020). Правова природа винагороди за правову до- помогу (гонорару) адвоката. Науковий вісник Ужгородського національного університету. Серія: Право, 61, Т. 2, С. 138-142.

10. Загальний кодекс правил для адвокатів країн Європейського Співтовариства (1988), прийнятий делегацією дванадцяти країн-учасниць на пленарному засіданні у Страсбурзі. URL: http://zakon2.rada.gov. ua/laws/show/994_343

11. Кияшко, О. О. (2019). Концепція «success fee» в межах проблематики відшкодування витрат на професійну правничу допомогу в цивільному процесі: судова практика. Новели иивільного процесуального законодавства. Представництво: матеріали Міжнар. наук.-практ. конф. до 150-ї річниці з дня відкриття першої судової палати у м. Одеса (с. 165-168). Одеса: Фенікс.

12. Князев, А. Н. (2005). Гонорар успеха в договоре оказания юридической помощи. Корпоративное управление и инновационное развитие экономики Севера. Вестник Научно-исследовательского центра корпоративного права, управления и венчурного инвестирования Сыктывкарского государственного универcumema, С. 103-109.

13. Корнелий Тацит (1993). Сочинения в двух томах. Том І. «Анналы. Малые произведения» / за ред. А.С. Бобович, Я.М. Боровский, М.Е. Сергеенко. М.: Науч.изд. центр «Ладомир». URL: http://ancientrome. ru/antlitr/t.htm?a=1347015000

14. Луспеник, Д. Д. (2019). Гонорар успіху адвоката: практика Європейського суду з прав людини. Судебно-юридическая газета. URL: https://sud.ua/ru/news/ publication/132954-gonorar-uspikhu-advokatapraktika-yevropeyskogo-sudu-z-prav-lyudini

15. Маслов, А. А. (2013). О гонораре адвокатов (honorarium) в Римской республике. Юридическая наука: история и современность, 11, С. 46-50.

16. Мельниченко, Р. Г. (2006). Достоинства и недостатки гонорара успеха. Адвокат, 10, С. 22-25.

17. Молло, М. (1894). Правила адвокатской профессии во Франции: пер. с франц. М.: Издание Н.П. Шубинского, 98 с.

18. Накушнова, Е.В. (2014). Вознаграждение исполнителя по договорам оказания правовых услуг (гонорар успеха). Современное право, 2, С. 79-84.

19. Памятники Римского права. Законы ХІІ таблии. Институции Гая. Дигесты Юстиниана (1997). М.: Зерцало. 608 с.

20. Папій, Т. О. (2019). Гонорар успіху адвоката: сучасний стан та перспективи розвитку в Україні. Порівняльно-аналітичне право, 4, С. 416-419. URL: http://pap. in.ua/4_2019/117.pdf 
21. Петрачков, С. С. (2010). «Гонорар успеха»: анализ правового регулирования в России и зарубежных странах. Вестник Московского государственного областного университета. Серия: Юриспруденция, 3. С. 68-74.

22. Постанова Великої Палати Верховного Суду (2020). No 904/4507/18. URL: https://reyestr.court.gov.ua/ Review/91572017

23. Постанова Касаційного цивільного суду у складі Верховного Суду (2018), о 462/9002/14-ц. URL: http:// reyestr.court.gov.ua/Review/75003682

24. Правила адвокатської етики (2017), затверджені Звітно-виборним з'їздом адвокатів України. URL: http://vkdka.org/wp-content/uploads/ 2017/07/ PravilaAdvokatskojiEtiki2017.pdf

25. Про адвокатуру та адвокатську діяльність. (2012): Закон України No 5076-VI. URL: https://zakon.rada. gov.ua/ laws/show/5076-17\#Text

26. Про розгляд звернення адвоката Дроздова О.М. щодо гонорару успіху адвоката за надану правничу (правову) допомогу (2019): рішення Ради адвокатів України No 35. URL: search.ligazakon.ua/L_doc2.nsf/link1/ MUS32051.html

27. Сарксян, С. М. (2017). Судьба «гонорара успеха» в судебной практике. Актуальные вопросы развития правовой информатизации в условиях формирования информационного общества: сборник статей Международной научно-практической конференции (с. 98-104). Стерлитамак: АМИ.

28. Чепкасов, Р.А. (2015). Понятие и правовая судьба «гонорара успеха». Новая наука: стратегии и векторы развития сборник Международной научно-практической конференции (с. 49-51). Стерлитамак: АМИ.

29. Access to Justice Act (1999). URL: www.legislation.gov. uk/ukpga/1999/22/section/27

30. Code suisse de déontologie (CSD) (2005), approuvé Fédération Suisse des Avocat. URL: https://www. oav.ch/wp-content/uploads/2016/06/code-suissedeontologie.pdf

31. Dudgeon v.The United Kingdom, 7525/76 (ECHR,1983). URL: http://hudoc.echr.coe.int/eng?i=001-57472

32. Gesetz über die Vergütung der Rechtsanwältinnen und Rechtsanwälte (2004). URL: https://www.gesetze-iminternet.de/rvg/

33. latridis v. Greece, $31107 / 96$ (ECHR, 2000). URL: http:// hudoc.echr.coe.int/rus?i=001-59087

34. Kamasinski v. Austria, 9783/82 (ECHR, 1989). URL: http://hudoc.echr.coe.int/eng?i=001-57614

35. Model Rules of Professional Conduct (1983), created by the American Bar Association. URL: https://www. americanbar.org/groups/professional_ responsibility/ publications/model_rules_of_professional_conduct/ rule_1_5_fees/

\section{References:}

1. Azarov, D. (2009). K voprosu o gonorare uspekha [On the question of the success fee]. Biznes $v$ zakone, 4 , 211-212. [in Russian].

2. Asanov, R. F. \& Akhmetov, S. F. (2007). "Gonorar uspekha»: zakonnost' i tselesoobraznost' [Success Fee: Legality and Feasibility.]. Yuridicheskaya nauka i pravookhranitel'naya praktika, 1, 44-50. [in Russian].

3. Vereshchagin, A. (2007). «Gonorar uspekha» pered litsom konstitutsionnogo pravosudiya [«Success Fee» in the Face of Constitutional Justice]. Sravnitel'noye konstitutsionnoye obozreniye, 1, 173-178. [in Russian].

4. Vishnevskaya, O. A. (2010). Institut oplaty uslug advokata v Drevnem mire [Institute of Advocate Payment in the Ancient World]. Advokatskaya praktika, 1, 41- 44. [in Russian].

5. Vityuk, R. (2018). Bonus dlya advokata: stymul chy koruptsiyna skladova? [Bonus for a lawyer: an incentive or a corruption component?] Zakon i biznes, 31 (1381). Available from: https://zib.com.ua/ua/133986-bonus dlya_advokata_stimul_chi_korupciyna_skladova.html [in Ukrainian].

6. Gvozdiy, V. (2018). Chy maye pravo na isnuvannya honorar uspikhu? [Is the success fee eligible for existence?] Komentar dlya «Zakon i Biznes», 31 (1381). Available from: https://zib.com.ua/ua/print/133986-bonus_dlya_advokata_stimul_chi_korupciyna_skladova. html [in Ukrainian].

7. Gorodnikov, K. I. \& Vorobyova, D. S. (2018). «Gonorar uspekha» v rossiyskoy pravovoy sisteme [ «Success fee" in the Russian legal system]. Sinergiya nauk. Available from: http://synergy-journal.ru/archive/article3827 [in Russian].

8. Yermakova, N. S. (2017). Gonorar uspekha: vzglyady za rubezhom i v Rossii [Success fee: views abroad and in Russia].Zakonnost'v sovremennom obshchestve: sbornik statey Mezhdunarodnoy nauchno-prakticheskoy konferentsii (pp. 122-126). Ufa: AETERNA. [in Russian].

9. Zaborovskyy, V.V., Manzyuk, V.V. \& Stoyka, A.V. (2020). Pravova pryroda vynahorody za pravovu dopomohu (honoraru) advokata [The legal nature of the fee for legal assistance (fee) of a lawyer]. Naukovyy visnyk Uzhhorods'koho natsional'noho universytetu. Seriya: Pravo, 61, T. 2, 138-142. [in Ukrainian].

10. Zagal 'ny j kodeks pravy'l dlya advokativ krayin Yevropejs`kogo Spivtovary'stva [General Code of Conduct for European Community Advocates], pry jnyaty`j delegaciyeyu dvanadcyaty` krayin-uchasny`cz` na plenarnomu 
zasidanni u Strasburzi. Available from: http://zakon2. rada.gov.ua/ laws/show/994_343 [in Ukrainian].

11. Kiyashko, O. O. (2019). Kontseptsiya «success fee» v mezhakh problematyky vidshkoduvannya vytrat na profesiynu pravnychu dopomohu $v$ tsyvil'nomu protsesi: sudova praktyka [The concept of «success fee» within the issue of reimbursement of professional legal assistance in civil proceedings: case law]. Novely tsyvil'noho protsesual'noho zakonodavstva. Predstavnytstvo: materialy Mizhnar. nauk.-prakt. konf. do 150-yi richnytsi z dnya vidkryttya pershoyi sudovoyi palaty u m. Odesa (pp. 165-168). Odesa: Feniks. [in Ukrainian].

12. Knyazev, A. N. (2005). Gonorar uspekha v dogovore okazaniya yuridicheskoy pomoshchi [Corporate governance and innovative development of the economy of the North]. Korporativnoye upravleniye i innovatsionnoye razvitiye ekonomiki Severa. Vestnik Nauchno-issledovatel'skogo tsentra korporativnogo prava, upravleniya i venchurnogo investirovaniya Syktyvkarskogo gosudarstvennogo universiteta, 103-109. [in Russian].

13. Korneliy Tatsit (1993). Sochineniya $v$ dvukh tomakh. Tom I. «Annaly. Malyye proizvedeniya» [Works in two volumes. Volume I. «Annals. Small works»] / za red. A.S. Bobovich, YA.M. Borovskiy, M.Ye. Sergeyenko. M.: Nauch.-izd.tsentr «Ladomir». Available from: http://ancientrome.ru/ antlitr/t.htm?a=1347015000 [in Russian].

14. Luspenik, D. D. (2019). Honorar uspikhu advokata: praktyka Yevropeys'koho sudu z prav lyudyny [Attorney's fee: the case law of the European Court of Human Rights]. Sudebno-yurydycheskaya hazeta. Available from: https://sud.ua/ru/news/publication/132954-gonorar-uspikhu-advokata-praktika-yevropeyskogo-sudu-z-prav-lyudini [in Ukrainian].

15. Maslov, A. A. (2013). 0 gonorare advokatov (honorarium) v Rimskoy respublike [On the honorarium in the Roman Republic]. Yuridicheskaya nauka: istoriya i sovremennost', 11, 46-50. [in Russian].

16. Melnychenko, R. G. (2006). Dostoinstva i nedostatki gonorara uspekha [The pros and cons of the success fee]. Advokat, 10, 22-25. [in Russian].

17. Mollo, M. (1894). Pravila advokatskoy professii vo Frantsii: per. s frants [Rules of the legal profession in France: trans. with French]. M.: Izdaniye N.P. Shubinskogo. [in Russian].

18. Nakushnova, Ye.V. (2014). Voznagrazhdeniye ispolnitelya po dogovoram okazaniya pravovykh uslug (gonorar uspekha) [Remuneration to the performer under contracts for the provision of legal services (success fee)]. Sovremennoye pravo, 2, 79-84. [in Russian].

19. Pamyatniki Rimskogo prava. Zakony XII tablits. Institut- sii Gaya. Digesty Yustiniana [Monuments of Roman law. Laws of XII tables. Guy's Institutions. Digests of Justinian]. (1997). M.: Zertsalo. [in Russian].

20. Papii, T. O. (2019). Honorar uspikhu advokata: suchasnyy stan ta perspektyvy rozvytku $\vee$ Ukrayini [Attorney's fee: the current state and prospects of development in Ukraine]. Porivnyal'no-analitychne pravo, 4, 416-419. Available from: http://pap.in.ua/4_2019/117. pdf [in Ukrainian].

21. Petrachkov, S. S. (2010). «Gonorar uspekha»: analiz pravovogo regulirovaniya $\vee$ Rossii i zarubezhnykh stranakh [Success Fee: Analysis of Legal Regulation in Russia and Foreign Countries]. Vestnik Moskovskogo gosudarstvennogo oblastnogo universiteta. Seriya: Yurisprudentsiya, 3, 68-74. [in Russian].

22. Postanova Velykoyi Palaty Verkhovnoho Sudu [Resolution of the Grand Chamber of the Supreme Court] (2020). No 904/4507/18. Available from: https://reyestr.court.gov. ua/Review/91572017 [in Ukrainian].

23. Postanova Kasatsiynoho tsyvil'noho sudu u skladi Verkhovnoho Sudu [Resolution of the Civil Court of Cassation of the Supreme Court] (2018), No 462/9002/14ts. Available from: http://reyestr.court.gov.ua/Review/75003682 [in Ukrainian].

24. Pravyla advokat.s'koyi etyky [Rules of Advocate Ethics] (2017), zatverdzheni Zvitno-vybornym z"yizdom advokativ Ukrayiny. Available from: http://vkdka.org/ wp-content/uploads/2017/07/PravilaAdvokatskojiEtiki2017.pdf [in Ukrainian].

25. Pro advokaturu ta advokatsku diialnist [On the Bar and Advocacy]. (2012). No 5076-VI. Available from: https://zakon. rada.gov.ua/laws/show/5076-17\#Text [in Ukrainian].

26. Pro rozhlyad zvernennya advokata Drozdova O.M. shchodo honoraru uspikhu advokata za nadanu pravnychu (pravovu) dopomohu [About consideration of the address of the lawyer Drozdov OM on the lawyer's fee for legal (legal) assistance] (2019): rishennya Rady advokativ Ukrayiny No 35. Available from: search.ligazakon.ua/l doc2.nsf/link1/MUS32051.html [in Ukrainian].

27. Sarksyan, S. M. (2017). Sud'ba "gonorara uspekha» $v$ sudebnoy praktike [The fate of the «success fee» in judicial practice]. Aktual'nyye voprosy razvitiya pravovoy informatizatsii $v$ usloviyakh formirovaniya informatsionnogo obshchestva: sbornik statey Mezhdunarodnoy nauchno-prakticheskoy konferentsii (pp. 98-104). Sterlitamak: AMI. [in Russian].

28. Chepkasov, R. A. (2015). Ponyatiye i pravovaya sud'ba "gonorara uspekha» [The concept and legal fate of the «success fee»]. Novaya nauka: strategii i vektory razvitiya sbornik Mezhdunarodnoy nauchno-prakticheskoy konferentsii (pp. 49-51). Sterlitamak: AMI. [in Russian]. 


\title{
«ГОНОРАР УСПІХУ" ЯК ВАЖЛИВА СКЛАДОВА ЗАБЕЗПЕЧЕННЯ КОНСТИТУЦІЙНОГО ПРАВА ОСОБИ НА ПРОФЕСІЙНУ ПРАВНИЧУ ДОПОМОГУ
}

\author{
Віктор Заборовський, \\ професор кафедри цивільного права та процесу Ужгородського національного університету, \\ доктор юридичних наук, професор \\ orcid.org/0000-0002-5845-7535
}

Scopus ID:

https://www.scopus.com/authid/detail.uri?authorld=57211590714

ResearcherID: Q-8219-2016

(https://publons.com/researcher/1590333/zaborovskyy-viktor/)

zaborovskyviktor@gmail.com

\section{Анотація}

Метою даної статті є дослідження правової сутності такого способу обчислення гонорару адвоката як «гонорар успіху», розкриття його позитивних та негативних рис, а також досвіду практики Європейського суду з прав людини та досвіду зарубіжних країн у його застосуванні.

у контексті розкриття предмета дослідення як для досягнення мети наукової роботи, так $і$ забезпечення повноти, об'єктивності, достовірності та переконливості отриманих результатів автором було застосовано комплекс загальнонаукових і спеціальних методів, що є характерними для правової науки. Зокрема, за допомогою історичного методу було досліджено зародження та тривалий історичний шлях розвитку даного правового інституту. Системно-структурний метод надав змогу сформулювати загальну структуру дослідження, а діалектичний - проаналізувати насамперед положення законодавства та судової практики щодо можливості використання «гонорару успіху» як способу обчислення гонорару адвоката. За допомогою порівняльно-правового методу, було проаналізовано законодавство зарубіжних країн, що надало можливість використання їх позитивного досвіду в аспекті обчислення розміру гонорару адвоката.

В даній статті розкриваються наукові підходи дослідників щодо визначення сутності витрат на правову допомогу насамперед, що стосується природи «гонорару успіху», позитивних та негативних його рис, а також аналізуються положення вітчизняного та зарубіжного законодавців щодо можливості закріплення в договорі про надання правової допомоги умови, яка свідчить про такий спосіб обчислення розміру оплати праці адвоката як «гонорар успіху». Значна частина роботи присвячена аналізу правозастосовної практики українських судів та Європейського суду з прав людини, як взагалі щодо можливості, так і щодо доцільності існування певних критеріїв обмеження його розміру.

Звертається увага, що значна кількість зарубіжнх країн не забороняють можливість використання «гонорару успіху», враховуючи насамперед наявність певних обмежень щодо категорій справ, або ж сприйняття його як додаткової винагороди.

На основі проведеного дослідження робиться висновок, згідно з яким враховуючи принцип свободи договору, адвокат і клієнт мають можливість зазначити у вказаному договорі умову щодо «гонорару успіху» як спосіб обчислення гонорару адвоката, за яким досягнення певного результату повинно сприйматись не як предмет договору, а саме як юридичний факт (відкладальна обставина), з настанням якого сторони обумовлюють необхідність здійснення оплати належної адвокату винагороди за досягнення ним відповідно рівня якості його діяльності. Аргументується, що позитивними рисами «гонорару успіху» є збільшення фінансової доступності надання правової допомоги для населення та його націленість на результат, що в багатьох випадках може покращити якість надання такої допомоги, а також захистити інтереси можливого клієнта адвоката від понесення ним зайвих витрат.

Ключові слова: адвокатура; гонорар адвоката; витрати на професійну правничу допомогу; способи обчислення розміру витрат; 